\title{
244. Eigen-Fremdhautplastik nach Mowlem-Jackson bei großflächigen Verbrennungen
}

\author{
F. H. KöPP-Grünstadt
}

Autodermic and Heterodermic Grafts According to Mowlem-Jackson in the Treatment of Extensive Burns

Summary. The principal aim of the Mowlem-Jackson graft is the early sealing of the wounds in patients with burns extending over large areas, using $50 \%$ of skin from the patient himself and $50 \%$ from a donor. A further advantage of this early plastic operation is that it prevents loss of plasma and secondary infection, resulting in a substantial improvement in the patient's general condition.

Used in conjunction with other progressive methods in the general care of patients with severs burns, the Mowlem-Jackson graft produces excellent results in restoring function and in the cosmetic field.

Zusammenfassung. Hauptziel der Mowlem-Jackson-Plastik ist der frühzeitige Wundversehluß großflächiger Brandwunden unter Verwendung von 50\% Eigenund $50 \%$ Fremdhaut. Ein weiterer Vorteil der frühzeitigen plastischen Operation ist die Eindämmung des Plasmaverlustes und die Verhinderung sekundär infektiöser Prozesse und damit der wesentlich bessere Allgemeinzustand des Patienten.

Verbunden mit den fortschrittlichen Erkenntnissen in der Allgemeinbehandlung Verbrennungskranker zeigt die Mowlem-Jackson-Plastik ausgezeichnete Ergebnisse im kosmetischen und funktionellen Bereich.

\section{Maschenlappen und Xenotransplantate zur Deckung ausgedehnter Verbrennungen}

\author{
H. Bohmert*, H. Seinfeld, G. Salzmann, W. Brendel und \\ H. W. SOLLINGER-München
}

Meshed Autografts and Xenografts to Cover Extensive Burns

Summary. In very extensive third-dregee burns, cutting the available healthy skin in the form of a mesh produces a much greater number of areas of epithelization. However, such grafts are exposed to lysis, infection and desiccation during the healing phase, and this conventional technique does not prevent infection and protein-loss on the wound surfaces. This led us to consider whether these disadvantages could be overcome by covering the area of the graft with a suitable material.

On the basis of preliminary investigations we decided that, for mechanical, biological and immunological reasons, fetal calf skin constituted a suitable covering material. The trials were carried out on dwarf pigs. In each animal, three standardized wounds were made on the rear part of the body. These were then covered with autologous meshed grafts and then each of the three wounds was further covered with either fetal calf skin, collagen foil or a moist bandage. Under the cover of these xenografts, which were first treated with nucleic acids, distinctly better healing took place than with any other method. The application of this 